\title{
ГОСУДАРСТВЕННАЯ ПОДДЕРЖКА ПРЕДПРИНИМАТЕЛЬСТВА В УСЛОВИЯХ ПАНДЕМИИ
}

\author{
(C) 2021 Цельникер Григорий Феликсович \\ кандидат юридических наук, доцент кафедры публичного права \\ Самарский государственный экономический университет, Россия, Самара \\ E-mail: grigorij-celniker@yandex.ru
}

\section{(C) 2021 Сидоренко Анастасия Валерьевна}

главный специалист отдела кадров, делопроизводства и организационной работы Департамент экономического развития, инвестиций и торговли

Администрации городского округа Самара, Россия, Самара

E- mail: nastya.sidorenko96@gmail.com

В статье рассматриваются особенности государственной поддержки предпринимательства в России. Также проводится сравнительный анализ государственной поддержки бизнеса в развитых странах. Определяются современные проблемы поддержки предприятий в РФ и даются рекомендации по улучшению сложившейся ситуации.

Ключевые слова: пандемия, государственные меры поддержки, бизнес, экономическая ситуация, кредитование, налоговые льготы, финансовая поддержка, кризис.

Борьба с пандемией COVID-19 в настоящее время является одной из ключевых проблем в глобальном масштабе. Российская Федерация является одним из субъектов, наиболее серьезно пострадавших от неблагоприятных последствий распространения вируса SARS-CoV-2.

Текущая экономическая ситуация в Российской Федерации не простая из-за снижения прибыли от продажи углеводородного сырья. В 2021 году доходы бюджета России снизились примерно на $12 \%$ по сравнению с предыдущим годом, а прибыль от продажи нефти и газа - примерно на 30\%. Сложное экономическое положение государства выражается в снижении доходов россиян, которые составили около 5\% ежегодно.

Все более ощутимые последствия пандемии для бизнеса и граждан заставили российские власти внедрить защитные программы. Изначально поддержка была оказана малым и средним предприятиям (МСП) и индивидуальным предприятиям (ИП), в основном в отраслях, наиболее пострадавших от кризиса.

Основной целью государственной помощи было поддержание занятости (это было одним из условий ее предоставления), тем более что предприниматели сильно пострадали от решения властей выплачивать зарплату рабочим во время обязательного простоя. Первоначально МСП и ИП могли рассчитывать только на налоговый мораторий (помимо НДС), сокращение или освобождение от взносов на медицинское страхование, а также на административные уступки. Например, до 1 июня 2020 года российскими властями введен мораторий на все проверки компаний (всего приостановлено около 400000 проверок)*. Только с мая МСП могли получать прямые субсидии от государства, а с июня уменьшенные ссуды (они могут быть погашены). В конце апреля 2020 года в Российской Федерации также начали поддерживать крупнейшие российские компании из правительственного списка компаний, имеющих системное значение для экономики (более 1100 корпораций).

Далее мы рассмотрим меры, разработанные Правительством РФ для поддержки экономического развития $*$ :

- ссуды и гранты для бизнеса (беспроцентный кредит на выплату заработной платы,

\footnotetext{
* Мораторий на проверки малого и среднего бизнеса могут продлить еще на год [Электронный источник] / Режим доступа: https://www.vedomosti.ru/economics/articles/2020/05/27/831188-prodlenie-moratoriya-naproverki._- Загл. с экрана (дата обращения 08.04.2021)

** План преодоления экономических последствий новой коронавирусной инфекции (подготовлен Правительством РФ). https://www.economy.gov.ru/material/dokumenty/plan_preodoleniya_ekonomicheskih_posledstviy_ novoy_koronavirusnoy_infekcii.html
} 
гранты на выплату заработной платы и другие срочные вопросы, если не менее 90\% персонала останется прежним, а 2/3 процентных выплат по новым займам покрываются за счет государство и банки);

- отсрочка и снижение налогов (кроме НДС) и страховых выплат на 6 месяцев для малого и среднего бизнеса в наиболее пострадавших отраслях. Для остальных организаций страховые взносы будут снижены вдвое на размер заработной платы, превышающей минимальный размер оплаты труда;

- отсроченные арендные платежи за государственное и муниципальное имущество;

- мораторий на возбуждение дел о банкротстве по заявлениям кредиторов для системообразующих предприятий и организаций наиболее пострадавших отраслей. Наиболее затронутые отрасли включают автомобильный транспорт, воздушный транспорт, туризм, выставочную деятельность, развлечения и досуг, культуру и спорт, общественное питание и розничную торговлю непродовольственными товарами. Этот список утвержден постановлением правительства и может быть расширен*.

Меры поддержки системообразующих предприятий включают:

- предоставление льготных кредитов сроком на 1 год для поддержания оборотных средств и сохранения рабочих мест;

- еженедельный мониторинг предприятий, стресс-тестирование и при необходимости оказание адресной поддержки.

Решение Центрального банка России от 24 апреля 2020 года о снижении базовой процентной ставки до 5,5\% (с 6\%) также стало важной поддержкой роста спроса в России. В начале мая президент банка заявил о готовности снизить его еще на 50 базисных пунктов.

Президент В.В.Путин, заявив о своей поддержке бизнеса в марте, также объявил об увеличении фискальной нагрузки с 2021 года, но только для более состоятельных людей. Это включает увеличение с $2 \%$ до 15\% налога на дивиденды, выплачиваемые иностранным организациям, и введение 13\% налога на доход от капитальных вложений и вложений в ценные бумаги на сумму свыше 1 миллиона рублей (около 12000 долларов США).
Рассмотрим практику применения различных форм государственной поддержки во время пандемии коронавируса отдельными странами (таблица 1).

Проведенный анализ показывает, что меры государственной поддержки реализуются в основном в кредитной сфере (льготное кредитование, предоставление государственных гарантий и др.) И в налоговой сфере (снижение налоговых ставок, предоставление отсроченных налоговых платежей). Был проведен сравнительный анализ размеров государственной поддержки в разных странах.

Рисунок 1 показывает, что в России масштабы финансирования государственных антикризисных мер самые низкие (около 1,2\% ВВП). Практически все развитые страны реализуют серьезные антикризисные программы, включая использование различных инструментов денежно-кредитной и налогово-бюджетной политики. Это связано с высоким риском потерь для экономики, если МСП уйдут с рынка, не имея резервов, произойдет сокращение производства, резкий рост безработицы, бедности и сокращение реальных доходов снизят спрос.

Развивающиеся страны принимают более скромные антикризисные меры, но это объясняется не столько необходимой финансовой поддержкой, сколько бюджетными возможностями государства.

Для Правительства РФ приоритетной задачей является определение потребности рынка и его отдельных субъектов в государственной поддержке. Развитие кризисных явлений в российской экономике может быть гораздо серьезнее, так как ситуация усугубляется сырьевой ориентацией экономики; что, в свою очередь, из-за резкого падения спроса на углеводороды падение цен на нефть на мировом рынке приведет к уменьшению доходной части бюджета.

Необходимо расширить пакет антикризисных мер и увеличить масштабы финансовой поддержки со стороны государства. Это возможно как за счет использования средств Фонда национального благосостояния (ФНБ), так и различных инструментов денежно-кредитной и фискальной политики.

Таким образом, российская экономика, пострадавшая от двух потрясений в 2020 году - пан-

\footnotetext{
* Постановление Правительства РФ от 03.04.2020 N 434 (ред. от 16.10.2020) «Об утверждении перечня отраслей российской экономики, в наибольшей степени пострадавших в условиях ухудшения ситуации в результате распространения новой коронавирусной инфекции»
} 
Таблиц̧а 1. Государственная поддержка бизнеса во время пандемии коронавируса в разных странах

\begin{tabular}{|c|c|c|c|c|}
\hline $\begin{array}{c}\text { Направление } \\
\text { поддержки }\end{array}$ & Китай & Великобритания & Швеция & Канада \\
\hline Кредитная зона & $\begin{array}{l}\text { Кредиты под нало- } \\
\text { говую задолжен- } \\
\text { ность, упрощение } \\
\text { процедуры выдачи } \\
\text { кредитов }\end{array}$ & $\begin{array}{l}\text { Беспроцентные } \\
\text { кредиты до } 1 \text { года, } \\
\text { кредитные и финан- } \\
\text { совые гарантии }\end{array}$ & $\begin{array}{l}\text { Увеличение кре- } \\
\text { дитных ресурсов и } \\
\text { государственных } \\
\text { гарантий, специ- } \\
\text { альная поддержка } \\
\text { экспортных произ- } \\
\text { водств. }\end{array}$ & $\begin{array}{l}\text { Доступные бизнес- } \\
\text { ссуды и беспро- } \\
\text { центные ссуды на } \\
\text { покрытие опера- } \\
\text { ционных расходов, } \\
\text { выдача льготных } \\
\text { ссуд арендатору для } \\
\text { снижения арендных } \\
\text { ставок }\end{array}$ \\
\hline Налоговая область & $\begin{array}{l}\text { Снижение налогов } \\
\text { (НДС, подоходный } \\
\text { налог, отмена стра- } \\
\text { ховки и социальных } \\
\text { льгот для работода- } \\
\text { телей) }\end{array}$ & $\begin{array}{l}\text { Налоговые льготы, } \\
\text { отсрочка платежей } \\
\text { по НДС, налоговые } \\
\text { каникулы до конца } \\
2021 \text { года для от- } \\
\text { дельных отраслей } \\
\end{array}$ & $\begin{array}{l}\text { Отсрочка уплаты } \\
\text { взносов на социаль- } \\
\text { ное страхование, } \\
\text { налога на заработ- } \\
\text { ную плату, НДС }\end{array}$ & $\begin{array}{l}\text { Отсроченный } \\
\text { подоходный налог, } \\
\text { федеральный налог } \\
\text { на товары и услуги и } \\
\text { налог с продаж }\end{array}$ \\
\hline $\begin{array}{l}\text { Бесплатная финан- } \\
\text { совая поддержка, } \\
\text { гранты и государ- } \\
\text { ственные инвести- } \\
\text { ции }\end{array}$ & $\begin{array}{l}\text { Инвестиции в от- } \\
\text { расли, создающие } \\
\text { рабочие места }\end{array}$ & $\begin{array}{l}\text { Гранты на по- } \\
\text { крытие текущих } \\
\text { бизнес-расходов, } \\
\text { государственная } \\
\text { выплата в размере } \\
80 \% \text { от заработной } \\
\text { платы сотрудников } \\
\text { за } 3 \text { месяца (макси- } \\
\text { мальная сумма } 2500 \\
\text { фунтов в месяц) }\end{array}$ & $\begin{array}{l}1 \text { миллион швед- } \\
\text { ских крон выделен } \\
\text { на поддержку куль- } \\
\text { туры и спорта. }\end{array}$ & $\begin{array}{l}\text { Субсидирование } \\
75 \% \text { заработной } \\
\text { платы работников } \\
\text { (до } 874 \text { долларов } \\
\text { в неделю), для } \\
\text { индивидуальных } \\
\text { предприятий - } \\
\text { 100\% компенсация } \\
\text { пенсионных выплат } \\
\text { работникам и взно- } \\
\text { сов на социальное } \\
\text { страхование. }\end{array}$ \\
\hline $\begin{array}{l}\text { Денежно-кредитная } \\
\text { политика }\end{array}$ & $\begin{array}{l}\text { Снижение нор- } \\
\text { мы обязательных } \\
\text { резервов для малых } \\
\text { и средних банков, } \\
\text { повышение доступ- } \\
\text { ности средств }\end{array}$ & $\begin{array}{l}\text { Обеспечение фи- } \\
\text { нансовой стабиль- } \\
\text { ности и доступности } \\
\text { кредита }\end{array}$ & $\begin{array}{l}\text { Обеспечение фи- } \\
\text { нансовой стабиль- } \\
\text { ности и доступности } \\
\text { кредита }\end{array}$ & $\begin{array}{l}\text { Снижение процент- } \\
\text { ных ставок, под- } \\
\text { держка финансового } \\
\text { рынка и ликвид- } \\
\text { ности финансовых } \\
\text { институтов }\end{array}$ \\
\hline
\end{tabular}

Источник: https://www.vedomosti.ru/economics/articles/2020/04/08/827470-pomogayut-malomu-biznesu

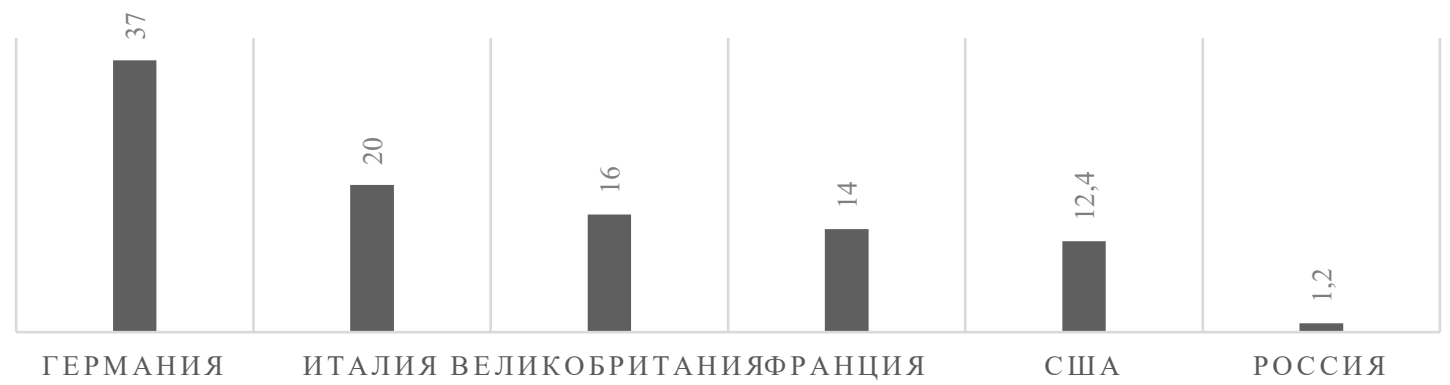

Рисунок 1. Сравнительная шкала антикризисных мер в России и других странах (в процентах от ВВП) Источник: составлено автором на основе https://www.rbc.ru/opinions/finances/15/05/2020/5ebbba4b9a7947e2a2e0001a 
демии COVID-19 и обвала цен на нефть,- вступила в третий кризис за последние 20 лет. Это делается в ситуации, когда еще не удалось избавиться от рецессии 2015 года. В последние годы в силу системных причин (централизованная и бюрократическая система управления, доминирование государства и слабая конкуренция, коррупция) в российской экономике наблюдается стагнация.

С точки зрения российского правительства, сильная поддержка малого и среднего бизнеса нежелательна. Это сектор, объединяющий активных, независимых граждан, которые обычно критически относятся к власти. Как следствие, за последние 20 лет, несмотря на официальные заявления о поддержке МСП, этот сектор дефакто подвергался преследованиям со стороны властей, и его доля в создании ВВП оставалась на очень низком уровне - около 20\%. Подход вла- стей к МСП отражается в экономической поддержке государством этого типа предпринимателей, в том числе в рамках программы помощи.

Нынешний кризис еще раз подчеркнул опасность зависимости России от сырьевого сектора. Падение спроса на энергоресурсы и падение цен на них в очередной раз нанесли удар по экономике в целом, лишив бюджет значительной части доходов. В то же время централизованный и контролируемый государством энергетический сектор в России не имеет стимулов для повышения своей конкурентоспособности. Учитывая сегодняшнюю реальность, государству для выхода из экономической рецессии, необходимо создать благоприятные условия для развития малого и среднего бизнеса, который в свою очередь будет локомотивом экономического и социального роста.

\section{Библиографический список}

1. Постановление Правительства РФ от 03.04.2020 N 434 (ред. от 16.10.2020) «Об утверждении перечня отраслей российской экономики, в наибольшей степени пострадавших в условиях ухудшения ситуации в результате распространения новой коронавирусной инфекции»

2. Как власти помогают малому и среднему бизнесу в разных странах [Электронный источник] / Режим доступа: https://www.vedomosti.ru/economics/articles/2020/04/08/827470-pomogayut-malomu-biznesu. - Загл. с экрана. (дата обращения 03.04.2021)

3. Помощь в дефиците: что показало сравнение антикризисных программ [Электронный источник] / Режим доступа: https://www.rbc.ru/opinions/finances/15/05/2020/5ebbba4b9a7947e2a2e0001ahttps://www.rbc.ru/ opinions/finances/15/05/2020/5ebbba4b9a7947e2a2e0001a - Загл. с экрана. (дата обращения 03.04.2021)

4. План преодоления экономических последствий новой коронавирусной инфекции (подготовлен Правительством РФ). https://www.economy.gov.ru/material/dokumenty/plan_preodoleniya_ekonomicheskih_posledstviy_ novoy_koronavirusnoy_infekcii.html

5. Мораторий на проверки малого и среднего бизнеса могут продлить еще на год [Электронный источник] / Режим доступа: https://www.vedomosti.ru/economics/articles/2020/05/27/831188-prodlenie-moratoriya-naproverki.- Загл. с экрана (дата обращения 08.04.2021) 